\title{
OPTIMASI SIFAT FISIK DAN MEKANIS BATAKO MENGGUNAKAN SEKAM PADI
}

\author{
Dafit Ardiansyah ${ }^{\mathbf{1}}$, Yusuf Amran ${ }^{2}$, Sari Utama Dewi ${ }^{3}$ \\ Program Studi Teknik Sipil Universitas Muhammadiyah Metro ${ }^{1,2,3}$ \\ E-mail : dafitardiansyah@gmail.com ${ }^{1}$, yusufamran307@gmail.com² ${ }^{2}$, \\ saridewi.dewi1981@gmail.com ${ }^{3}$
}

\begin{abstract}
ABSTRAK
Tujuan dari penelitian ini adalah untuk mengoptimalkan bahan susun dan proses produksi batu bata sekam padi yang dicetak secara manual tanpa mesin dengan memenuhi standar SNI 03-0349-1989 tentang bata beton atau batako. Penelitian ini menggunakan metode eksperimen yang dimulai dari penyelidikan blok bangunan, pembuatan batu bata dan pengujiannya. Bahan bata susun antara lain semen, pasir, dan sekam padi dicampur dalam berbagai variasi metode, pencetakan dilakukan secara manual tanpa bantuan mesin sesuai SNI 03-0349-1989, pengujian dilakukan terhadap kuat tekan dan bata resapan air dengan semen bahan susun: pasang, sekam padi dengan perbandingan 1:8:5\% akan menghasilkan kuat tekan tertinggi pada umur tujuh hari dengan penambahan $1 \%$ sekam padi sebesar $82.469 \mathrm{~kg} / \mathrm{cm} 2$, pada umur dua puluh delapan hari dengan penambahan sekam padi $2 \%$ sebesar $78.025 \mathrm{~kg} / \mathrm{cm} 2$, dan kuat tekan batu bata di pasaran sebesar 23.704 $\mathrm{kg} / \mathrm{cm} 2$. sedangkan syarat lulus benda uji menurut SNI 03-0349-1989 adalah $25 \mathrm{~kg} / \mathrm{cm} 2$.
\end{abstract}

Kata Kunci : Bata Sekam Padi.

\section{PENDAHULUAN}

Exploitasi tanah liat sebagai bahan utama pembuatan batu bata merah juga akan berdampak pada kerusakan lingkungan. Maka dari itu perlu adanya inovasi untuk menciptakan bahan bangunan yang lebih ramah lingkungan. Salah satunya adalah dengan beralih ke bata beton atau batako.Penggunaan bata dan batako sebagai bahan bangunan pembuatan dinding yang sudah populer dan menjadi pilihaan utama masyarakat di Indonesia sampai dengan saat ini, namun dari bahan-bahan mempunyai kelemahan tersendiri yaitu berat permeter kubiknya yang cukup besar sehingga berpengaruh terhadap besarnya beban mati yang bekerja pada struktur bangunan. Selain bentuk batako yang utuh, bagi pelaksana kontruksi kekuatan batako merupakan tolak ukur kualitas bangunan. Bangunan dengan kualitas yang baik membuat penghuni didalamnya merasa aman dan nyaman.untuk batako sebagai material penyusun dinding, kekuatan desak yang diizinkan harus memenuhi standar SNI Nomor 03-0349-1989 tentang bata beton. Kekuatan tekan batako yang diizinkan minimal adalah $21 \mathrm{~kg} / \mathrm{cm}^{2}$

Dari kenyataan di atas, diperlukan penelitian lanjutan tentang batako sekam padi yang dicetak dalam posisi tidur dan tidak menggunakan mesin cetak. Karena batako sekam padi memiliki berat yang lebih ringan dibanding dengan batako konvesional, Selain sifat-sifat fisik dan mekanis batako yang diuji, penelitian ini juga akan menganalisis harga batako hasil penelitian yang kemudian akan dibandingkan dengan harga batako sejenis dipasaran. 


\section{TINJAUAN PUSTAKA}

\section{Semen}

Menurut SNI 15-0302-2004, Portland Pozzolan Cement adalah semen hidrolis yang terdiri dari campuran yang homogen antara semen portlanddan pozzolan halus yang terbentuk ketika penggilingan klinker yang mengandung material penting seperti kalsium silikat. Fungsi semen yaitu untuk merekatkan butiran-butiran agregat, selain itu juga untuk mengisi rongga-rongga antar agregat sehingga menjadi suatu masa yang padat.

\section{Pasir}

Pasir adalah contoh bahan material yang berbentuk butiran. Butiran pasir, umumnya berukuran antara 0,0625 sampai $2 \mathrm{~mm}$. materi pembentuk pasir adalah silikon dioksida, tetapi beberapa pantai tropis dan subtropis dibentuk dari batu kapur. Hanya bebrapa tanaman yang dapat tumbuh diatas pasir, karena rongga-rongganya yang besar.Pasir memiliki warna sesuai dengan pembentukannya.Pasir juga penting untuk bahan bangunan bila dicampur semen.

Air

Air merupakan kebutuhan dalam pembuatan batako, salah satunya ketika air dicampur dengan semen portlandmaka akan terjadi reaksi kimia yang terkandung dalam semen portland. Reaksi kimia dengan air ini disebut "hidrasi". Hasil dari reaksi kimia ini menentukan bagaimana semen portlandmengeras dan memperoleh kekuatan. Air yang digunakan dalam pembuatan batako harus menggunakan air yang bersih. Air yang mengandung garam, minyak, asam, alkali atau bahan lainnya tidak boleh digunakan karena akan mengurangi kualitas batako.

\section{Sekam Padi}

Sekam padi adalah bagian terluar dari butiran padi (kulit padi).Sekam padi dapat dianggap sebagai produk sampingan agroindustri yang berasal dari penggilingan padi.Sisa-sisa tanaman ini mewakili sekitar $20 \%$ berat padi yang dipanen. Karenanya, pertanian padi menghasilkan hampir 15,8 juta ton sekam padi di Indonesia.

\section{Kuat tekan}

Kuat tekan adalah besanya beban persatuan luas, yang menyebabkan benda uji hancur apabila dibebani dengan gaya tekan tertentu, yang dihasilkan oleh mesin pembebanan. Kuat tekan batako mengidentifikasikan mutu dari sebuah batako.Semakin tinggi kuat tekan batako, semakin tinggi pula mutu batako yang dihasilkan.Batako harus dirancang proporsi campurannya agar menghasilkan kuat tekan yang disyaratkan. Pengujian kuat tekan batako dimaksudkan untuk mengetahui kuat tekan batako dalam menahan gaya tekan.

Untuk menghitung besarnya kuat tekan dapat dihitung menggunakan persamaan.

$\sigma=\frac{P}{A}$

Dimana;

$\sigma=$ kuat tekan $\left(\mathrm{kg} / \mathrm{cm}^{2}\right)$

$\mathrm{P}=$ beban $(\mathrm{kg})$

A $=$ luas penampang $\left(\mathrm{cm}^{2}\right)$

\section{Penyerapan Air}

Penyerapan air merupakan presentase berat air yang mampu diserap oleh benda uji. Pengujian penyerapan air bertujuan untuk mengetahui kadar air dalam batako. Dalam memperoleh nilai kadar penyerapan air dapat dilihat dalam Persamaan.

Penyerapan air $=\frac{A-B}{B} X 100 \%$

Keterangan :

$\mathrm{A}=$ Berat basah

$\mathrm{B}=$ Berat kering 


\section{Kelayakan Harga Produksi}

Kelayakan harga produksi perlu dilakukan untuk mengetahui apakah batako sekam padi layak untuk diproduksi dan apakah dapat bersaing dengan batako yang dijual dipasaran.Permasalahan ini menyebabkan perusahaan biasanya mengadakan penetapan harga yang disepakati sebelum produk beredar dipasaran.Oleh karena itu, untuk memperoleh harga produksi perlu dilakukan perhitungan nilai produksi yang bertujuan untuk mencari kalayakan harga dalam memproduksi batako sekam padi yang layak untuk dipasarkan.Dalam penghitungan harga produksi, komponen-komponen biaya yang dipertimbangkan adalah biaya alat, biaya operasional, biaya upah, biaya material, biaya konsumsi dan biaya tunjangan hari raya. Pada penelitian ini akan dilakukan perhitungan perbandingan harga pokok produksi batako penelitian dengan harga pokok produksi batako dipasaran.

\section{METODE PENELITIAN}

\section{Pengumpulan Data Melalui Pengamatan Proses Produksi}

Selama proses produksi, akan diamati bagaimana proses produksinya, apakah terdapat kesulitan untuk mencetak produk batako secara utuh tanpa cacat, dan berapa buah produksi batako per harinya, berapa volume bahan susun yang diperlukan untuk membuat satu unit batako, berapa lama waktu siklus dalam pembuatan batako mulai dari mencampur, mengaduk, mencetak, dan memindahkan ke tempat teduh.

\section{Pengujian Laboratorium}

Terdapat beberapa pengujian dalam penelitian ini, yaitu pengujian bahanbahan penyusunnya (kadar air, berat volume) dan pengujian sampel batako (penyerapan air dan kekuatan desak).

a) Pengujian Bahan-Bahan Penyusun

Bahan-bahan penyusun adalah semen, filler (semen), dan sekam padi. Pengujian meliputi kadar air, dan berat volume. Pedoman pengujian mengikuti standar pengujian di Laboratorium Teknik Sipil

b) Pengujian Sampel Batako Terdapat dua pengujian, yaitu penyerapan air dan kekuatan desak. Pengujian ini dilakukan terhadap benda uji yang telah berumur 28 hari. Untuk pengujian kuat desak benda uji berupa batako. Pengujian kuat desak dilakukan untuk masing-masing varian tipe sebanyak 3 (tiga) buah dengan menggunakan alat uji desak manual di Laboratorium Teknik sipil, Universitas muhammadiyah metro.

\section{Pengumpulan Data Melalui Analisis Harga Pokok Produksi}

Pengumpulan data melalui analisis harga pokok produksi tidak hanya dilakukan dengan perhitungan harga produksi batako, Survei harga bahan penyusun batako juga perlu dilakukan untuk mendapatkan data yang diperlukan. dilakukan dengan wawancara dengan pihak yang berkompeten sesuai dengan data yang dicari.

a. Objek Penelitian

Objek penelitian ini adalah harga pokok produksi batako dan harga jual batako dengan sekam padi.

b. Data yang diperlukan Data yang diperlukan untuk menghitung harga pokok produksi adalah :

1) Biaya alat

2) Biaya bangunan

3) Biaya operasional

4) Biaya papan dasar

5) Biaya upah pekerja

6) Biaya material batako

7) Biaya makan

c. Metode Pengumpulan Data

1) Wawancara

2) Dokumentasi

3) Studi pustaka 
Tahap Analisis Data dan Pembahasan

Pada tahap ini dilakukan pengolahan data dari pengujian yang telah dilakukan.Datadata yang telah diperoleh dianalisis untuk mendapatkan tipe batako mana yang paling baik sesuai dengan kriteria menurut SNI.Kemudian dilakukan pembahasan terkait hasil pengujian yang diperoleh.

\section{HASIL PENELITIAN}

Pada penelitian ini peneliti membahas tentang komposisi campuran batako, kuat tekan, penyerapan air, dan estimasi harga batako. Pada penelitian pengujian batako dilabolatorium mengacu pada parameter- parameter yang berada dilapangan, karena pada peneliti ini membahas tentang perbandingan harga jual batako tanpa campuran (adiktif) dan batako dengan campuran (sekam padi), dimana parameter dan spesifikasi batako meliputi ukuran cetakan batako, Campuran adukan semen dan pasir/ komposisi campuran dan metode relasi, serta perawatan disetarakan dengan apa yang ada dilapangan, yang membedakan hanyalah campuran adiktif (sekam padi) pada batako.

Tabel 1. Kebutuhan Campuran Batako

\begin{tabular}{|l|c|c|c|c|c|}
\hline No & $\begin{array}{l}\text { Variasi } \\
\text { campuran }\end{array}$ & $\begin{array}{l}\text { semen } \\
(\mathbf{k g})\end{array}$ & $\begin{array}{l}\text { Pasir } \\
(\mathbf{k g})\end{array}$ & $\begin{array}{l}\text { Sekam } \\
\text { padi } \\
(\mathbf{k g})\end{array}$ & $\begin{array}{l}\text { Jumlah } \\
\text { sampel }\end{array}$ \\
\hline 1 & $1: 8: 0 \%$ & 0,6 & 1.271 & 0,00 & 3 \\
\hline 2 & $1: 8: 1 \%$ & 0,6 & 1.271 & 0,06 & 3 \\
\hline 3 & $1: 8: 2 \%$ & 0,6 & 1.271 & 0,012 & 3 \\
\hline 4 & $1: 8: 3 \%$ & 0,6 & 1.271 & 0,018 & 3 \\
\hline 5 & $1: 8: 4 \%$ & 0,6 & 1.271 & 0,024 & 3 \\
\hline 6 & $1: 8: 5 \%$ & 0,6 & 1.271 & 0,030 & 3 \\
\hline
\end{tabular}

(Hasil Pengujian Di Laboratorium, 2021)

\section{Menentukan Kebutuhan Air}

Dalam pembuatan batako kebutuhan air ditentukan dengan trial lapangan atau uji coba, dengan cara mencampurkan air sedikit-sedikit dan aduk secara merata hingga mencapai kondisi yang diinginkan seperti ketika campuran dapat digenggam, bisa menggumpal dan dapat melekat menandakan bahwa campuran sudah dapat dicetak.

\section{Kebutuhan Sekam Padi}

Pada pembuatan batako yang ditambahkan dengan campuran sekam padi sebanyak $0 \%, 1 \%, 2 \%, 3 \%, 4 \%, 5 \%$, dari komposisi campuran tersebut maka sekam padi yang akan ditambahkan pada pembuatan batako yang dihitung dari berat semen dalam satu benda uji $(0,6$ $\mathrm{kg}$ ).

\section{Wawancara di Lapangan}

Wawancara adalah kegiatan tanya jawab secara lisan untuk memperoleh imformasi. Bentuk informasi yang diperoleh dinyatakan dalam tulisan, atau direkam secara audio visual. Wawancara merupakan kegiatan utama dalam kegiatan pengamatan dan sebagai bahan acuan untuk pembuatan karya ilmiah (batako) dilaboratorium Teknik UM metro.

\section{Pengujian Kuat Tekan Batako}

Pengujian kuat tekan batako dilakukan pada umur 7 hari, 28 hari, dan batako di pasaran jumlah benda uji untuk masing-masing adalah 3 buah. Variasi kadar penambahan sekam padi yaitu: $0 \%$, $1 \%, 2 \%, 3 \%, 4 \%, 5 \%$. total pembuatan benda uji sebanyak 39 buah batako, 18 buah batako untuk umur 7 hari, 18 buah batako untuk umur 28 hari, dan 3 buah batako di pasaran. Kemudian setelah mencapat umur batako yang ditentukan dilakukan pengujian kuat tekan untuk mendapatkan nilai kuat tekan batako dalam satuan $\mathrm{kg} / \mathrm{m} 2$ menggunakan alat uji kuat tekan (compression test). 


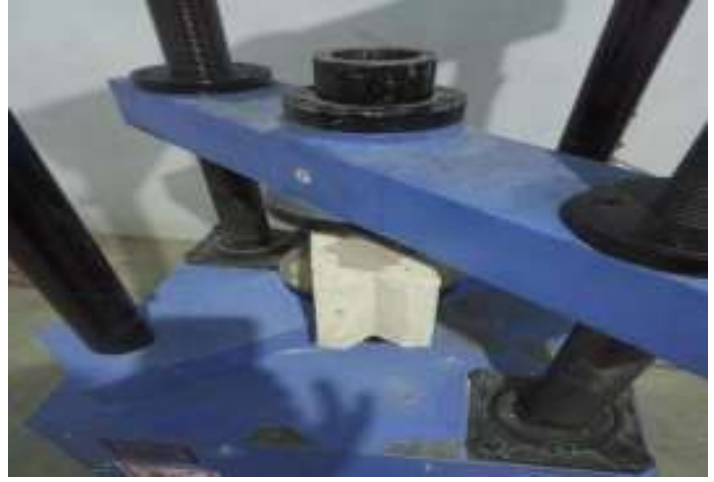

Gambar 1. Proses Pengujian Kuat Tekan Batako

Menurut SNI 03-0349-1989 tentang bata beton untuk pemasangan dinding, kuat tekan minimun untuk bata beton pejal yaitu $25 \mathrm{~kg} / \mathrm{cm}^{2}$ dan $21 \mathrm{~kg} / \mathrm{cm}^{2}$, Hasil pengujian tersebut kemudian disajikan dalam grafik perbandingan campuran Semen : pasir : Sekam Padi dan kuat tekan bruto seperti Gambar grafik berikut ini.

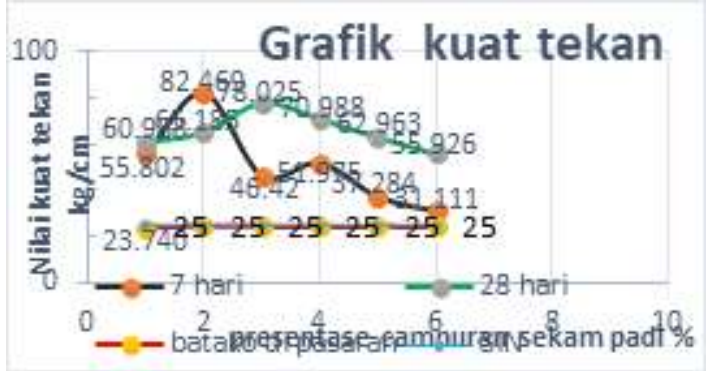

Gambar 2. Grafik Hasil Uji Kuat Tekan Batako

Dilihat dari tabel diatas hasil kuat tekan batako dapat dianalisa, dengan bertambahnya umur batako maka semakin meningkat kuat tekannya dan menunjukan bahwa semakin banyak presentas campuran maka akan berkurang kuat tekan batako. Terjadinya penurunan kuat tekan batako dengan campuran sekam padi disebabkan Karena sekam padi prinsipnya bisa menyerap air terhadap adukan/ campuran batako dan mengurangi kadar air pada batako, sehingga membuat adukan batako menjadi kekurangan air, yang mengakibatkan hasil benda uji kuat tekan batako mendapatkan nilai uji kuat tekan yang rendah. Dilihat dari tabel diatas hasil kuat tekan dengan komposisi campuran 5\% mendapatkan nilai kuat tekan yang rendah diumur 7 hari maupun 28 hari batako, hasil ini sejalan dengan hasil pengujian penyerapan air yang bisa dilahat pada gambar 18 yang menunjukan kondisi batako basah menggunakan adiktif (sekam padi) presentase $1 \%$ mempunyai nilai penyerapan air paling kecil diantara keempat komposisi campuran/ adukan batako tersebut, hal ini sesuai dengan kriteria yang dijelaskan pada SNI 03-0349-1989 tentang bata beton. Untuk hasil pengujian kuat tekan umur 7 hari nilai tertinggi campuran adukan batako versi $1 \%$ dengan nilai $82.469 \mathrm{~kg} / \mathrm{cm}^{2}$. Untuk pengujian kuat tekan umur 28 hari nilai tertinggi campuran adukan batako versi $2 \%$ dengan nilai $78.025 \mathrm{~kg} / \mathrm{cm}^{2}$.

\section{Pengujian Penyerapan Air}

Daya serap air adalah presentase berat air yang mampu diserap oleh suatu agregat jika direndam dalam air. Dalam penelitian ini, benda uji harus direndam pada air dalam kurun waktu 24 jam. Perendaman dilakukan untuk mendapatkan hasil penyerapan air maksimum berdasarkan SNI 03-03491989 yaitu sebesar 25\%. Pengujian dilakuka pada batako umur 28 hari dengan menggunakan benda uji $0 \%, 1 \%$, $2 \%, 3 \%, 4 \%, 5 \%$, jumlah benda uji masing-masing 3 buah.Hasil pengujian penyerapan air kemudian disajikan dalam bentuk kurva hubungan perbandingan campuran Semen : pasir : Sekam Padi dengan penyerapan air (\%) seperti berikut ini : 


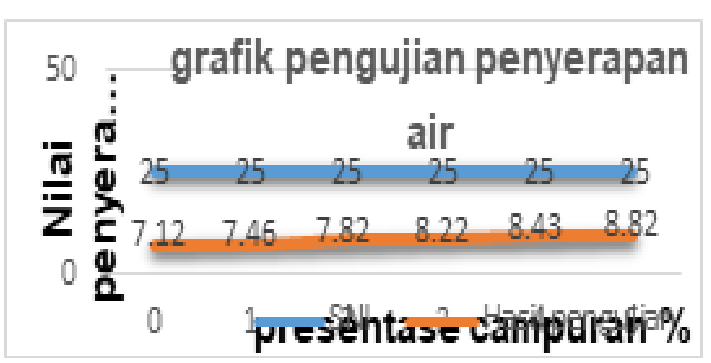

Gambar 3. Hasil Pengujian penyerapan Air Pada Batako

Pengujian Penyerapan air bertujuan untuk mengetahui nilai jumlah air yang bisa menyerap kedalam batako. Hasil pengujian penyerapan air pada batako menggunakan sekam padi, dilihat dari tabel diatas menunjukan nilai penyerapan air semakin tinggi presentase campuran batako sekam padi maka semakin tinggi penyerapan air pada batako. Dikarenakan sekam padi mempunyai kandungan kadar air yang cukup tinggi walaupun proses hidrasi telah selesai.

\section{Analisis Perbandingan Kelayakan Harga Batako}

Pada analisis kelayakan harga batako untuk menentukah harga satuan dicari dengan cara survei di lapangan, agar mendapatkan nilai-nilai harga satuan alat dan bahan untuk membuat batako.

Dalam menentukan perbandingan hargabatako di pasaran sebuah survey telah dilaksanakan pada penjual batako diwilayah metro, batako di pasaran memiliki ukuran $30 \mathrm{~cm}$ x $9 \mathrm{~cm} \times 15 \mathrm{~cm}$, jumlah pendapatan batako perhari 250 pcs dengan jumlah pekerja 2 orang, harga jual batako sebesar Rp 2500,-/batako. Batako hasil penelitian disetarakan dengan yang ada dilapangan yang membedakan hanyalah campuran adiktif (sekam padi) pada batako.Untuk menentukan kelayakan harga batako dilakukan dari hasil pengujian pembuatan batako dengan variasi penambahan sekam padi $5 \%$, dan jumlah batako yang didapatkan mengikuti dari hasil wawan cara dilapangan, dalam satu hari dua pekerja menghasilkan 250 pcs/hari batako.
Dari perhitungan harga produksi tersebut, diperoleh biaya produksi yang harus dikeluarkan perhari yaitu sebesar Rp 563.400,- dengan produksi batako 250 batako/hari. Harga pokok pokok produksi yaitu sebesar $\mathrm{Rp} 2.530$, sedangkan harga jual perbatako sebesar Rp 3.000, dari harga tersebut didapatkan Keuntungan sebesar Rp 470,/batako, uraian perhitungan harga produksi tersebut mengacu pada campuran batako variasi $5 \%$ yaitu dengan perbandingan semen : pasir : sekam padi sebesar $1: 8$ : $5 \%$ dengan harga jual per batako sebesar Rp 3.000.

\section{KESIMPULAN}

Pada pengujian campuran yang dibuat sample kemudian diuji kuat tekan, batako yang dicetak pada posisi tidur tanpa menggunakan mesin memiliki kuat tekan yang memenuhi standar SNI 030349-1989, tertinggi untuk umur 7 hari yaitu batako variasi $1 \%$ yaitu sebesar $82.469 \mathrm{~kg} / \mathrm{cm}$ dan umur 28 hari tertinggi yaitu variasi $2 \%$ sebesar $78.025 \mathrm{~kg} / \mathrm{cm}$, pada varisi lainnya juga memenuhi standar SNI, namun semakin banyak tambahan sekam padi maka semakin remdah pula kuat tekannya.

Pada pengujian penyerapan air, semua variasi pada batako yang dicetak pada posisi tidur tanpa menggunakan mesin memenuhi standar penyerapan air maksimum yang disyaratkan SNI 0303491989. Jika dilihat dari hasil pengujian penyerapan air pada bab IV dapat disimpulkan bahwa semakin banyak penambahan campuran sekam padi maka semakin besar penyerapan airnya.

Dari hasil perhitungan harga sebuah batako sekam padi yang dicetak secara manual tanpa menggunakan mesin memiliki harga sebesar Rp 3.000 sementara itu harga batako dipasaran sebesar $\mathrm{Rp} 2500$. dengan harga batako Rp 3.000 masih dianggap efektip atau layak dipasarkan, dikarenakan 
perbandingan harganya tidak terlalu jauh hanya selisih 500 rupiah. Dari tabel kuat tekan pada bab IV, kuat tekan batako harus memenuhi standar SNI 03-03491989 tentang bata beton kuat tekan yang diijinkan minimum $25 \mathrm{~kg} / \mathrm{cm} 2$, pengujian kuat tekan yang telah dilakukan, batako di pasaran memiliki nilai kuat tekan $23,704 \mathrm{~kg} / \mathrm{cm} 2$ (tidak memenuhi standar SNI), dan batako hasil penelitian dengan penambahan sekam padi memiliki nilai kuat tekan tertinggi umur 7 hari 82,469 $\mathrm{kg} / \mathrm{cm} 2$ dan batako umur 28 hari 78,025 $\mathrm{kg} / \mathrm{cm} 2$, pada dasarnya batako hasil penelitian $0 \%, 1 \%, 2 \%, 3 \%, 4 \%, 5 \%$ pada umur 7 ari dan 28 hari memenuhi standar SNI 03-0349-1989.

\section{DAFTAR PUSTAKA}

A. G. Tamrin, teknik kontruksi bangungan gedung jilid 1. Jakarta Direktorat Pembinaan Sekolah Menengah Kejuruan, Direktorat Jendral Menejemen Pendidikan Dasar dan Menengah, Dapartemen Pendidikan Nasional. Tahun 2008

Badan Standarisasi Nasional, Bata Beton Untuk Pasangan Dinding. SNI (030349-1989)

Badan Standarisasi Nasional, Portland Pozzolan Cement (PPC). SNI (150302-2004)

Chandra Prasetya, Arif Rahman, Remba Yanuar Efranto. Analisa desain eksperimen pembuatan batan batako berbahan alternatip lumpur lapindo dan ply ash dengan metode taguchi

Dapartemen pekerjaan umum, 1992. persyaratan umum bahan bangunan diindonesia, PUBI-1992,

Kamus besar bahasa indonesia (KBBI).

Lexiy j, moleong, Teknik Analisis Data.

Nguyen, T.T., Picandet, V., Amziane, S., Baley, C, 2009. Influence of Compactness and Hemp Hurd Characteristics on the Mechanical Properties of Lime and Hemp
Concrete, Euro Journal of Environmental Civil Engineering

Persyaratan Umum Bahan Bangunan di Indonesia $(P U B I, 1982)$

Standar nasional indonesia (SNI, 030349-1989) Bata Beton.

Standar nasional indonesia (SNI, 15-0302-2004) Portland pozzolan cement.

Yusuf amran ST.MT 2016, Pemanfaatan Limbah Plastik Untuk Bahan Tambahan Pembuatan Paving Block Sebagai Alternatif Perkerasan Pada Lahan Parkir Universitas Muhammadiyah Metro. Yusuf amran, Rivan rinaldi, 2017. pemanfaatan abu ampas tebu sebagai bahan campuran untuk memperbaiki sifat fisik dan mekanis bata. 